\title{
Problems and Prospects of the Cooperative Movement in India under the Globalization Regime
}

\author{
Dr. Saroj Kumar $\operatorname{Singh}^{1 *}$
}

\section{ABSTRACT}

This paper intends to analyze the problems prospects of cooperative sector in India under free market. It is now, increasingly recognized that the co-operative system in India has the capacity and potentiality to neutralize the adverse effects emerging from the process of globalization. After economic liberalization under the new economic environment, cooperatives at all levels are making efforts to reorient their functions according to the market demands. The failure of the public sector in several cases is a worrisome trend. Privatization has also failed to make an impact in the rural areas. Therefore, there is great hope on the cooperative sector. The paper examines the causes of slow progress and highlights the emerging role and challenges of the cooperative sector. In comparison to the step-motherly treatment of the past, cooperatives are now, considered an important plank of development. The government is committed to cooperative development. The cooperatives have inherent advantages in tackling the problems of poverty alleviation, food security, and employment generation. Cooperatives are also, considered to have immense potential to deliver goods and services in areas where both the state and the private sector have failed. The paper focuses on several pitfalls and shortcomings like: poor infrastructure, lack of quality management, over-dependence on government, dormant membership, non-conduct of elections, lack of strong human resources policy, absence of professionalism, etc. It suggests evolving strong communication and public relations strategies, which can promote the concept of cooperation among the masses. It should also push forward by developing effective strategies to overcome existing weaknesses and for continuing growth of the sector. The paper assesses the future prospects of the cooperative sector of India.

Keywords: Co-operative Sector, Globalization, Liberalization, Privatization.

Around the world modern cooperatives have developed for over 200 years. Cooperative institutions exist all over the world providing essential services, which would otherwise be

\footnotetext{
${ }^{1}$ Department of Rural Economics, S. N. S. R. K. S. College Saharsa, (A constituent unit of B. N. Mandal University, Madhepura) Bihar, India

*Responding Author

(C) 2016 I S Singh; licensee IJIP. This is an Open Access Research distributed under the terms of the Creative Commons Attribution License (http://creativecommons.org/licenses/by/2.0), which permits unrestricted use, distribution, and reproduction in any Medium, provided the original work is properly cited.
} 
unattainable. In many Third World countries, cooperatives such as credit unions and agricultural organizations have been very successful in helping people to provide for themselves where private and other corporate capitals do not see high profitability. In 90 countries of the world, over 700 million individuals are members of cooperative institutions. Globally, cooperatives have been able to elevate its position as a powerful economic model. In some countries, they are a sizeable force within the national economy.

During the British rule, Nicholson a British Officer in India suggested to introduce Raiffersen model of German agricultural credit Cooperatives in India. As a follow-up of that recommendation, the first Cooperative Society Act of 1904 was enacted to enable formation of "agricultural credit cooperatives" in villages in India under Government sponsorship. With the enactment of 1904 Act, Cooperatives were to get a direct legal identity as every agricultural Cooperative was to be registered under that Act only. The 1904 Cooperative Societies Act, was repealed by 1912 Cooperative Societies Act which provided formation of Cooperative societies other than credit. Under 1919 Administrative Reforms act, Cooperatives was made a provincial subject making each province responsible for Cooperative development. In 1942, the British Government enacted the Multi-Unit Cooperative Societies Act, 1942 with an object to cover societies whose operations are extended to more than one state. The impulses of the Indian freedom movement gave birth to many initiatives and institutions in the post-independence era in India and armed with an experience of 42 years in the working of Multi Unit Cooperative Societies and the Multi-Unit Cooperative Societies Act, 1942. The Central Government enacted a comprehensive Act known as Multi State Cooperative Societies Act 1984,repealing the Act of 1942.

\section{Growth of Cooperative Sector in India}

India has basically an agrarian economy with $72 \%$ of its total population residing in rural areas . The rural people need lot of services in daily life which are met by village co-operative societies. The seeds of cooperation in India were sown in 1904 when the first Cooperative Societies Act was passed. Since then, the cooperative movement has made significant progress. Cooperatives have extended across the entire country and there are currently an estimated 230 million members nationwide. The cooperative credit system of India has the largest network in the world and cooperatives have advanced more credit in the Indian agricultural sector than commercial banks. The village cooperative societies provide strategic inputs for the agricultural sector, consumer societies meet their consumption requirements at concessional rates; marketing societies help the farmer to get remunerative prices and co-operative processing units help in value additions to the raw products etc. In addition, co-operative societies are helping in building up of storage go-downs including cold storages, rural roads and in providing facilities like irrigation, electricity, transport, and health. Various development activities in agriculture, small industry marketing, and processing, distribution and supplies are now carried on through cooperatives. In fertilizer production and distribution the Indian Farmers Fertilizer Cooperative 
(IFFCO) commands over 35 percent of the market. In the production of sugar, the cooperative share of the market is over 58 percent and in the marketing and distribution of cotton, they have a share of around 60 percent. The cooperative sector accounts for 55 percent of the looms in the hand-weaving sector. Cooperatives process, market and distribute 50 percent of edible oils. Dairy cooperatives operating under the leadership of the National Dairy Development Board and through 15 state cooperative milk-marketing federations has now become the largest producer of milk in the world. The groundwork for this was laid in the early 1970's when the largest dairy development programme in the world - Operation Flood - was launched. Operation Flood was a national marketing strategy linked to a dairy infrastructure development programme that created a chain of dairy processing plants, collection stations and a national milk transportation grid. With the passage of the Insurance Act, cooperatives have been allowed to entry into the insurance business. Insurance is a field where the immense potential of cooperatives remains untapped. The Indian Farmers Fertilizer Cooperative has recently teamed up with a Japanese company and formed a joint venture for undertaking general insurance business in India. This signifies that Indian cooperatives have come of age in formulating strategic alliances. Thus, the co-operative societies in India in fact are playing multi-functional roles both in rural and urban areas. An Expert Group constituted by the Government of India in 1990,recommended i) to facilitate building up of integrated co-operative structure; ii) to make the co-operative federation organizations responsive towards their members; iii) to minimize government interference and control in the functioning of co-operatives and iv) to eliminate politicization from the cooperative sector. Based on the recommendations, the central government enacted the Multi State Cooperative Societies Act, 2002 that provided for democratic and autonomous working of the Cooperatives, which came into force with effect from August 19, 2002. Various development activities in agriculture, small industry marketing and processing, distribution and supplies are now carried on through co-operatives. The co-operatives in India have made an allround progress and their role in, and contribution to agricultural progress has particularly been significant.

\section{Structure and Significance of Cooperatives}

The cooperative structure in India consists of different constituents. At the bottom of this structure are the primary societies, which render various types of services. Of this large number about $80 \%$ is concerned with agriculture. Most of these societies, about $60 \%$ deal with credit only. Thus a large majority of primary societies are related to agriculture and credit. They perform various functions such things as credit, irrigation, marketing, transports etc. These are generally divided into two groups (i) credit societies and (ii) noncredit societies Each of these two sub groups is further split up into sub groups: 9(a) agricultural societies and (b) non agricultural societies. Agricultural societies (both credit and noncredit are found in rural areas, but nonagricultural societies both credit and noncredit) are found in urban areas. For supervision and financial assistance to cooperative credit societies there are central banks and state cooperative banks. The central banks supervise the functioning of the primary societies of a 
district or art of a district and offer financial assistance to them. Their capital is drawn from public deposits, share capitals and loans from other sources. Because of variety of sources from which these banks can draw money, they act as a link between cooperative societies and the money market. They function as balancing centers by diverting funds of surplus societies to the needy societies. They also perform ordinary banking functions also. At the top of the cooperative credit is the state cooperative bank, at the state level, known as the apex bank. It controls the working of central banks and provides finance to them. It also acts as the link between reserve bank f India from which it borrows and the central banks and primary societies. It directs the cooperative movement in the state. Its capital comes from share capital, public deposits and loans and advances from the state and Reserve bank of India. The National Cooperative Union of India is the apex organization promoting the cooperative movement in the country.

All the above three types of institutions are concerned with short and medium term credit of people. Long-term loans are given by Land Development banks, which have a unitary structure having branches at different places. These banks obtain their funds from share capital, reserves, deposits, issue of bonds and debentures. However the major part of their resources is drawn from the floating of ordinary debentures in the market. The investors in these debentures are LIC, commercial banks, Cooperative banks, central and state governments and Reserve bank of India. Cooperation in a vast country like India is of great significance because:

- It is an organization for the poor, illiterate, and unskilled people

- It is an institution of mutual help and sharing

- It softens the class conflicts and reduces the social cleavages

- It reduces the bureaucratic evils and follies of political factions

- It overcomes the constraints of agricultural development

- It creates conducive environment for small and cottage industries

The share of Co-operatives in National economy is as follows:

\begin{tabular}{|l|l|}
\hline Rural Network (villages covered) & $100 \%$ \\
\hline Agricultural Credit disbursed by Co-operatives & $46.15 \%$ \\
\hline Agricultural Credit disbursed by Co-operatives & $46.15 \%$ \\
\hline Fertilizer disbursed (6.049 million Tons) & $36.22 \%$ \\
\hline $\begin{array}{l}\text { Fertilizer production (3.293 M.T. - N\&P) } \\
\text { Nutrient }\end{array}$ & $27.65 \%$ \\
\hline Sugar produced (10.400 million tons) & $59.0 \%$ \\
\hline Capacity Utilization of Sugar Mills & $111.5 \%$ \\
\hline Wheat Procurement (4.50 million tons) & $31.8 \%$ \\
\hline Animal Feed Production/Supply & $50 \%$ \\
\hline Retail Fair Price Shops (Rural + Urban) & $22 \%$ \\
\hline Milk Procurement to Total Production & $7.44 \%$ \\
\hline
\end{tabular}

(c) The International Journal of Indian Psychology, ISSN 2348-5396 (e)| ISSN: 2349-3429 (p) | 157 
Problems and Prospects of the Cooperative Movement in India under the Globalization Regime

\begin{tabular}{|l|l|}
\hline Milk Procurement to Marketable surplus & $10.5 \%$ \\
\hline Ice Cream Manufacture & $45 \%$ \\
\hline Oil Marketed (Branded) & $50 \%$ \\
\hline Spindale in Co-operatives (3.518 million) & $9.5 \%$ \\
\hline Cotton Marketed / Procurement & NA \\
\hline Cotton yarn/Fabrics Production & $23.0 \%$ \\
\hline Handlooms in Co-operatives & $55.0 \%$ \\
\hline Fishermen in Co-operatives (Active) & $21 \%$ \\
\hline Storage Facility (Village level PACS) & $65.0 \%$ \\
\hline Rubber processed and marketed & $95.0 \%$ \\
\hline Areca nut processed and marketed & $50 \%$ \\
\hline Direct employment generated & 1.07 million \\
\hline Self-Employment generated for persons & Direct employment generated \\
\hline Salt Manufactured (18,266 Metric Tons) & $7.6 \%$ \\
\hline
\end{tabular}

The statistics indicates that modern cooperative movement has made tremendous progress in every walk of its activities and occupies a major place in the share of the national economy.

\section{Types of Cooperatives}

The Co-operative Movement was introduced into India by the Government as the only method by which the farmers could overcome their burden of debt and keep them away from the clutches of the moneylenders. The Government of India passed the Co-operative Credit Societies Act, 1904 and rural credit societies were formed. Through the appointment of registrars and through vigorous propaganda, the Government attempted to popularize the Movement in the rural areas. Within a short period, the Government realized some of the shortcomings of the 1904 Act and, therefore, passed a more comprehensive Act, known as the Co-operative Societies Act of 1912. This Act recognized non-credit societies also. However, the rural credit societies have continued to be predominant till now.

(1) The Primary Agricultural Credit/Service Societies: The agricultural co-operative credit structure in the Punjab State is broadly divided into two sectors, one dealing with the short-terms and medium-terms finance and the other with the long-term credit. In the State, the short-term and medium-term credit structure is based on a three-tier system, i.e., the Apex Co-operative Bank at the State level, the Central Co-Cooperative Bank at the district/tehsil level and the Primary Agricultural Credit Societies at the village level. The major objectives of the primary agricultural credit service societies are to supply agricultural credit to meet the requirements of funds for agricultural production, the distribution of essential consumer commodities, the provision of storage and marketing facilities and for light agricultural implements and machinery. Owing to an increasing emphasis on the development of land and agriculture, longtermco-operative credit has assumed great importance. There is the Punjab State Land Mortgage Bank at the Apex and the Punjab Mortgage Bank at the district/tehsil level. These Primary Land

(c) The International Journal of Indian Psychology, ISSN 2348-5396 (e)| ISSN: 2349-3429 (p) | 158 
Mortgage Banks advance loans to the farmers for long-term purposes. At the operational level, there exists a primary co-operative to extend credit to the farmer. This unit epitomizes the vitality and service potential of the Co-operative Movement in India. The organization of these societies dates back to 1904, when the first Co-operative Societies Act was passed. These societies were started to providing cheap credit to the agriculturists in order to free them from the clutches of the rapacious moneylenders. The agricultural primary credit society is the foundation stone on which the whole co-operative edifice is built. Even now, these societies dominate the co-operative picture.

The first Agricultural Credit Society in the Firozpur District was registered on 4 October 1911, at the Village of Khalchi Kadim in the Firozpur Tehsil. Originally, the movement was confined to the credit societies only and, thus, credit dominated till the partition (1947). After the partition, the Co-operative Movement began to spread to other field, viz. labour, construction and farming. In 1979-80, the number of agricultural cooperative credit societies in the District was 309 with a membership of $1,21,761$. The loan advanced during the same year amounting to Rs. 2,180.35 lakh and the deposits to Rs. 26.84 lakh.

(2) Agricultural Non-Credit Societies: While credit is and must remain for some time the chief concern of the Co-operative Movement relatively slow, since 1912, when the non-credit societies were brought officially under the aegis of the Movement. the World War II (1939-45) came as a God send boon with respect to the development of the Cooperative Movement. Prices of agricultural goods began to rise and touched new peaks. The repayment of loans was accelerated and deposits began to pour in. The number of societies also rose. Another interesting development in co-operative during the War was the extension of the Movement to non-credit activities, viz. consumer's co-operative marketing societies, consolidation societies, etc. The number of agricultural non-credit societies in the district was 38 in 1978-79.

(3) Agricultural co-operative Marketing Societies: Marketing has occupied a far smaller place in the co-operative picture in India than in many countries, notably Denmark and the USA, but not other non-credit line of co-operation, with the possible exception of the consolidation of land holdings and joint farming enterprises, seems to hold greater possibilities of help to the agricultural population of India. The development of co-operative marketing in India is closely bound up with the problem of credit-the claims of the moneylenders commonly inhibiting the cultivator's freedom of action in disposing of his crop. The full utilization of loans advanced depends upon the arrangements for the marketing of surplus produce. For this purpose, there the Punjab State Marketing Federation at the State Level, wholesale societies at the district level and Marketing societies at the market level. These societies also provide other agricultural facilities and make arrangements for the supply of domestic items in the rural areas. In 1979-80, there were 10 agricultural co-operative marketing societies in the district, with a total membership of 5,982 (5,056 individuals and 926 societies). During the same year, their paid-up capital was Rs. 19.70 lakh and the working capital Rs. 558.52 lakh, and they marketed goods worth Rs. 992.08 lakh. At the State level, the Punjab State co-operative Supply and Marketing Federation (MARKFED) is playing an important role in building up an integrated structure for remunerative 
marketing and storing of agricultural produce. It has played an important role in hastening the Green Revolution in the State by arranging ready supplies of essential farm inputs needed by the cultivators.

(4) Co-operative Farming Societies: The Royal Commission on Agriculture in 1928 observed that it co-operation failed, there would fail the hope of the Indian agriculturist. Co-operative farming is a compromise between collective farming and the peasant proprietorship and gives all merits of large-scale farming without abolishing private property. It implies an organization of the farmers on the basis of common efforts for common interests. Under this system, all landowners in a village form a co-operative society for tilling the land. The land is pooled, but each farmer retains the right of property. The produce is distributed by each. They are allowed to withdraw from the cooperative farm whenever they desire. In India, the exceedingly small size of holdings is perhaps the most serious defect in our agriculture. If agriculture has to be improved, the size of the holdings must be enlarged. The co-operative farming societies, thus, enable the cultivators to enjoy the economies of large-scale farming through the pooling of land management resources.

\section{Causes of Slow Progress}

Despite rapid growth the overall progress of cooperative movement during 100 years of its existence is not very impressive. It is therefore necessary to know the causes of poor performance of the movement and on that basis take such steps as would promote a faster growth of cooperative movement in India.

a. Government Interference:

The cooperative movement in India was initiated in 1904 under the auspices of British government. Right from the beginning, the government has adopted an attitude of patronizing the movement. Cooperative institutions were treated as if these were part and parcel of the administrative set up of the government. The government interference thus became essential elements in the working of these institutions. As a result, people's enthusiasm for the movement did not grow. The movement's independence and self-reliance existed only on paper and files. After attainment of independence, in particular after beginning of the planning, some healthy changes in the attitude of the government did take place. It was not given proper importance that it deserves in any plan. But even the cooperative movement has not become full-fledged people movement. Even today quite often cooperative societies are imposed upon the people. This does bring about an increase in the membership of the societies. However, the spirit of cooperation cannot flower fully in these circumstances. Neither it growth took place according to any plan nor did it become a people's movement. It just grew very slowly and that too haphazardly. It was a state driven institution.

\section{b. Mismanagement and Manipulation:}

The essence of the cooperative movement is that it gives the farmers the status of shareholders and assures them agricultural, educational and medical facilities. Under the Maharashtra State Cooperatives Act, a minimum of 11 farmers is required to form a cooperative. Today the 
shareholder membership averages between 15,000 and 25,000 farmers. The relationship between the shareholder farmer and the cooperative is simple - the farmer is committed to contributing a certain amount of cane per season and the mill is bound to take this cane. The strength of the movement was the involvement of the farmers who were shareholders in the sugar mill regardless of the size of their holdings. Over the years, this truly democratic idea got corrupted and farmers with larger holdings grew more powerful. In practice, this altered the power structure of the cooperatives. In the elections to the governing bodies of the sugar factories, money became such a powerful tool that the top posts of chairman and vice-chairman usually went to the richest farmers even though the majority of members were farmers with small- or medium-sized holdings.

\section{c. Lack of Awareness:}

People are not well informed about the objectives of the movement, the contributions it can make in rebuilding the society and the rules and regulations of cooperative institutions. Unfortunately, no special efforts have been made in this direction. People look upon these institutions as means for obtaining facilities and concessions from the govt. So long as people expect to get something from the government, they see to it that societies somehow continue to function. Lack of education, dirty politics of the village, caste-ridden elections to the offices of cooperative societies, bureaucratic attitudes of the government officers at the lower rank are some of the hurdles in spreading the correct information about the cooperative movement and in educating the people about its true character and vital role in the society.

\section{d. Restricted Coverage:}

The cooperative movement has also suffered on account of two important limitations on its working. One is that the size of these societies has been very small. Most of these societies are confined to a few members and their operations extended to only one or two villages. As a result, their resources remain limited, which I make it impossible for them to expand their means and extend there are of operations .Two, the most of the societies have been single purpose societies. For this reason these societies are unable to take a total view of the persons seeking help, nor can they analyze and solve problems from different angles. By assessing the persons and the problems only from one angle, these societies neither help properly the person nor make an optimal use of their resources. Under these circumstances, it has not been possible for these societies to make much progress.

\section{e. Functional Weakness:}

The cooperative movement has suffered from inadequacy of trained personnel right from its inception. Lack of trained personnel has been caused by two major factors. In the first place, there has been a lack of institutions fort this purpose of training personnel. Secondly, because of it unsatisfactory working of cooperative institutions, efficient personnel did not feel attracted or motivated towards them. The functioning of the cooperative societies, too suffer from several weakness. Such weakness has prevented them from progressing on healthy lines. Thus, there are several pitfalls. Poor infrastructure, lack of quality management, overdependence on government, dormant membership, non-conduct of elections, lack of strong human resources 
policy, neglect of professionalism, etc. are the limiting factors. Indian cooperatives are also unable to evolve strong communication and public relations strategies, which can promote the concept of cooperation among the masses.

\section{Future Prospects: Democratic Reforms Warranted}

Reforms are warranted in order to overcome its short comings and consolidate its strengths . Reorganizing the Primary Societies.: The first and foremost improvement concerns the reorganization of primary societies so that they can function properly. For this reorganization, three steps are called for: One, The weak and inefficient societies should be winded and merged with strong and efficient societies. It will no doubt reduce the number of societies, but this is itself not a bad thing. Otherwise, the weak societies would undermine people's confidence in the movement and cause a setback to it from a long-term point of view. Two, small societies should be merged to build a larger societies. With large amount of resources at its disposal, big societies can avail certain facilities, which small societies cannot secure. For example, these societies can afford to engage highly trained and competent personnel and thus conduct their business efficiently. Besides, these societies can to some extent, face some deficits and bear the burden of over dues of their members. Smaller societies cannot do either of these. It is for these reasons so many societies in India are idle and dormant. Of course, small societies have intimate knowledge about their members. However, because of scanty resources these societies neither function efficiently not are able to do much for their members. On the contrary, the size should not be too large. It became difficult to keep proper control over the functioning of the society. Therefore, Mehta committee suggested for "one village one society." Thirdly, instead of single purpose societies multipurpose societies need to be organized superficially single -purpose societies appear to be more useful because each one would concentrate on a specified function. However, experience suggests that unless problems of the people are viewed and solved in an integrated way, the cooperative movement can make only limited progress. Multipurpose societies can have a balanced view about the needs of its members and can meet them accordingly. As result the resource of such societies are utilized efficiently and at the same time members derive the greatest possible advantages from the resources placed at their disposal. During last few years, the cooperative movement has gained much from the formation of such multipurpose societies.

It has to ensure efficiency in it functioning. Therefore the importance measures are needed. Firstly, the loan from credit societies should be granted in such a manner and under such conditions that these are used productively and not misused. It is in this way that the recourses of the movement will be correctly used and their repayment is ensured. It is only then that the problem of over dues can be properly tackled. Secondly, it is necessary to maintain close coordination of activities among different constituents of the cooperative structure: primary societies at the base, organization at the central and state levels should be right type. Their relations and the coordination among their working should be so institutionalized that they work 


\section{Problems and Prospects of the Cooperative Movement in India under the Globalization Regime}

together, mutually helping instead of opposing one another. Similarly there should be close integration among cooperative institutions, Reserve Bank, State Bank, Commercial Banks, and National Bank of Agriculture and Rural Development and the Government .But it does mean that the government or any other institution should adopt a patronizing attitude towards it. However, there should be collaboration and coordination to promote the cooperative movement among the people. Thirdly, it is necessary to enlist the services of trained administrators and devoted workers in order to impart efficiency to its working and humanize its functioning. It is also essential that the procedures of work of cooperatives should be made simple, straight and convenient. The hold of the bureaucracy should be done away with.

It is necessary to spread the movement as people's movement. People should not think it as a part of the government or a department of the government People should own it and manage it. People should be educated and about the advantages of this movement.

Educational institutions at various levels, radio, TV, newspapers, poster, and other mass media can be used for this purpose. Secondly, government participation and support is necessary. But it should not be patronage or interference or domination. It should facilitate its growth in healthy lines. Thirdly, the cooperative movement should be conceived and developed as a part of the national economy. Along with private and public sector, it should be treated as a separate sector in its own right. In fact, of the three sectors, the cooperative sector alone can claim to be peoples sector with human face under globalization framework. Therefore for its growth, more resources should be allocated under the five year plans of the government. Fourthly, there is need for extending the cooperative activities in all the regions of the country. The north -eastern states are lagging behind. Fifthly, there is urgent need for helping the weaker sections and vulnerable groups like SC and ST to form cooperatives in order to be free from the exploitation of intermediaries. Therefore, appropriate concession and facilities should be extended to such societies. Finally, there should be research and continuous monitoring and inspection about the problems and constraints of different cooperative societies. It will help to overcome the difficulties and proceed further with success. Cooperative movement will be an important impetus for rapid rural development of the country.

\section{Concluding Remarks}

After independence, India marched with central planning in order to achieve economic development. The new economic policy of globalization after eighties has reduced the dominant role of the state. The pendulum of economic growth in India is swinging from over commitment of public sector to over enthusiasm of the private sector. The urban sector is growing impressively very fast in India . The growth rate of service sector has become very impressive but the agricultural sector has lagged behind. The problem of poverty and unemployment among common people poses a real dilemma between the role of the State and role of the market forces. 
Market forces fail to unleash forces for growth and at the most, it tends to generate low-income activities horizontally.

This process fits perfectly well with an investment pattern and production structure to sub serves a social milieu and life style, which has no relevance for the broad mass of the rural people. It has created a dangerous process of marginalization and contractualisation (Das 1993) As a result the economic vulnerability and livelihood insecurity manifests. There is inherent urban bias in the formulation of macro adjustment policies. It is creating a system which is ultimately as centralized and undemocratic as any that can be imposed by the meddlesome bureaucracy. Its success can at best be treated as a pyrrhic victory, when means win and ends lose. Market is never friendly to the poor people or backward regions. It creates sharp regional imbalance. Majority of the rural sector and the unskilled and illiterate section of the urban sector tend to lose their right to livelihood and economic citizenship. Vicious circle of poverty manifests in different forms. There is also the growth of dangerous tendency of the elite to dismiss the deep concern towards poverty and economic vulnerability as the obsession toward egalitarian romantics. They strongly believe myopically in the trickledown theory.

There is now increasing indifference towards the problem of poverty and inequality. Expansionist economic reforms during the 1990s boosted economic growth but high level of poverty and unemployment persist in India. Despite impressive economic growth, the powerful wave of consumerism, computerization, and corruption coexists in social life of India. It puts over emphasis on high-tech efficiency of industrial sector and modern urban service sector at the cost of rural sector, where majority eke out their living. One must always remember one simple thing that any model of development, which ignores India's rich endowment of human resources and rich natural resources including land and water resources, is bound to falter. Any development route which bypasses the rural people of India is unlikely to be sustainable. Salvation of the developing economy as vast and diverse as India's lies only in the transformation and revitalization of its rural economy, which require people's empowerment and participation. One's sense of idealism is in direct proportion to one's distance from the real scenario. Neither private sector nor public sector shall promote social welfare. India requires meaningful reforms in the cooperative sector, before complete -opening up its economy to the competitive regime, which should ensure: a). higher standard of living for the village people. b) Production for mass consumption. In comparison to the step motherly treatment of the past, cooperatives should be considered an important plank of development. The cooperatives have inherent advantages in tackling the problems of poverty alleviation, food security and employment generation. Cooperatives have immense potential to deliver goods and services in areas where both the state and the private sector have failed.

(C) The International Journal of Indian Psychology, ISSN 2348-5396 (e)| ISSN: 2349-3429 (p) | 164 
Problems and Prospects of the Cooperative Movement in India under the Globalization Regime

\section{Acknowledgments}

The author appreciates all those who participated in the study and helped to facilitate the research process.

\section{Conflict of Interests}

The author declared no conflict of interests.

\section{REFERENCES}

Hanumantha, Rao, B. B. Bhattacharya , N S Siddharthan (2005), “Indian Economy and Society in the Era of Globalisation and Liberalisation”, Academic Foundation, Delhi $439 \mathrm{p}$

Parthasarathy, G. (2003) "Economic Reforms and Rural Development in India," Academic Foundation, Delhi

Radhakrishna, R. S.K. Rao, S. MahendraDev and K.Subbarao (2006), "India in a GlobalisingWorld :Some Aspects of Macro Economy, Agriculture And Poverty”, 528p, Academic Foundation, Delhi .

Vaidyanathan, A. (2003), “India's Economic Reforms and Development” Academic Foundation, Delhi .

Alderman, Harold (1987), “Cooperative Dairy Development in Karnataka, India”, International Food Policy Research Institute, Washington.

Das, Kumar (1993) “Rural Development Through Decentralzation, Discovery” Pub. House, Delhi. 180p

Eleanor, Margaret Hough, K. Madhava Das (1967), “Cooperative Movement in India” (Ed): Oxford University Press, 506p

Hanumantha, Rao C H( 2005 ), “Agricultural Growth, Farm Size And Rural Poverty Alleviation In India,” 398p

Samantaray, P.C. (2004), "Hundred Years of Co-operative Movement: Emerging Issues and Challenges,” Orissa Review.

Singh GurusharanK. (1998), “India's Rural Cooperatives” edited, Vedam Books, Delhi, 456 p.

Singh Ram Binod (2006),”Gandhian Approach to Development Planning”. New Delhi, Concept, $278 \mathrm{p}$.

Gupta, S. P. (2006) “Globalisation, Economic Reforms and Employment Strategy in India,” 276

Deb, Alok Kumar (2006), “World Cooperative Movement”, www.cooperativemovementindia. com

How to cite this article: S Singh (2016), Problems and Prospects of the Cooperative Movement in India under the Globalization Regime, International Journal of Indian Psychology, Volume 3, Issue 4, No. 59, ISSN 2348-5396 (e), ISSN: 2349-3429 (p), DIP: 18.01.073/20160304, ISBN: 978-1-365-26307-1

(C) The International Journal of Indian Psychology, ISSN 2348-5396 (e)| ISSN: 2349-3429 (p) | 165 